LORENZOVÁ, J.: „Komunita a její role v občanské společnosti“. In: Kraus, B., Poláčková, V. et al. 2001. Člověk - prostředi - výchova. K otázkám sociální pedagogiky. Brno: Paido, s. 119-125.

LORENZOVÁ, J. 2001. „Komunitní vzděláváni a komunitní škola“. In: Kraus, B., Poláčková, V. et al. Člověk - prostředí - výchova. K otázkám sociálni pedagogiky. Brno: Paido, s. 137-142.

LORENZOVÁ, J. 2001. „Pomáhání a pomáhající profese“. In: Kraus, B., Poláčková, V. et al. Clověk-prostředi - výchova. K otázkám sociální pedagogiky. Brno: Paido, s. 173-182.

VALENTA, J. 2000. Učit se být. Témata a metody pro osobnostní a sociálni výchovu. Praha-Kladno: STROM-AISIS, s. 95.

VALENTA, J. 2001. Výzkumný projekt ověrováni osobnostni a sociâlní výchovy ve školni praxi. Praha: FF UK, katedra pedagogiky, s. 12.

VALıŠOVÁ, A. 2001. „Problems of Authority in education“. In: Lust am Lehren. Klagenfurt: Leuchtturm-Verlag, s. 459-462.

VALIŠOVÁ, A. 1999. „Nezbytnost 'vůle k vůli' (vzájemné podněty praktické filozofie a pedagogiky)“. In: O filozofii výchovy a filozofii provádějicí (sborník praci věnovaný univ. prof. dr. Jaroslavě Peškové k jejim 70. narozeninám). Praha: FF UK, s. 83-89.

VALIŠOVÁ, A. 2000. Asertivita na prahu 21. století. Praha: RAABE, s. 1-16.

KRYKORKOVÁ, H., CHVÁL, M.: „Rozvoj metakognice - cesta k hodnotnějšímu poznání“. In: Pedagogika. č. 2, 2001, s. 185-196.

PELIKÁN, J. 2001. Pomáhat být. Otevřené otázky teorie provázející výchovy. AUC, Phil et Hist., Mono CLXI, Praha: Karolinum, s. 160.

MATĚJƯ, M. a kol. 1999. Kulturni a sociálni změny v lokálni společnosti - výzkum občanů 1992-98. Praha: FF UK.

MATËJŮ, M. a kol. 1999. Sociokulturni potenciál a vzdělanost v provesu revitalizace lokální společnosti. Praha: FF UK.

MATËJƯ, M. a kol. 2000. Transformace městských komunit v kontextu evropských integračnich procesủ (I. Český Krumlov, II. Blatná, III. Velké Meziříčí). Praha: FF UK.

MATĚJƯ, M. a kol. 2001. Transformace městských komunit. Kulturní a sociální změny v lokálni společnosti. Monografická studie. Výzkum obyvatel mĕsta Blatná. Informace z výzkumu prováděného v letech 1992 až 2000. Praha: katedra teorie kultury FF UK.

MATĚJÜ, M. a kol. 2001. Transformace městských komunit. Kulturni a sociální změny v lokálni společnosti. Monografická studie. Výzkum obyvatel města Český Krumlov. Informace z výzkumu prováděného $v$ letech 1992 až 2000. Praha: katedra teorie kultury FF UK.

MATĚJŮ, M. a kol. 2001. Transformace městských komunit. Kulturni a sociální změny v lokální společnosti. Monografická studie. Výzkum obyvatel města Velké Meziř̌čí. Informace z výzkumu provádĕného $v$ letech 1992 až 2000. Praha: katedra teorie kultury FF UK.

HAVRÁNEK, J., KOTRBÁČEK, J. 2000. „Konkurenční postavení zemědělských výrobců a jeho dủsledky“. In: Sborník: Transformation, Stabilization and Growth. Brno: MU, s. 131-144.

\title{
Život dvou vynikajících polských sociologů se uzavřel
}

Polská i světová sociologie utrpěla v létě roku 2001 citelnou ztrátu: 12. 7. zemřela Antonina Kłoskowská (nar. 7. 11. 1919) a 4. 8. skonal Edmund Mokrzycki (nar. 6. 1. 1937). Ačkoli byli přislušníky rủzných generací, získávajícími první poznatky o sociologii a zahajujícími svou vědeckou i pedagogickou dráhu v rozdílných dobách a za rủzných okolností, mnohé měli společné. Oba navazovali na nejlepši tradice polské sociologie, oba v řadě oborů sociologické práce tyto tradice tvořivým způsobem rozvíjeli, oba svými díly nepřehlédnutelným způso- bem obohatili sociologickou teorii, metodologii i některé odvětvové sociologické discipliny, oba mají výraznou zásluhu na tom, že polská sociologie se jako celek ani v období socialismu nezpronevěři la vědeckým standardům a oba získali i mezinárodní ohlas.

Antonina Kłoskowská ukončila studium sociologie na sklonku čtyřicátých let a hned poté začala vědecky a pedagogicky pracovat v Sociologickém 
institutu Lodžské univerzity, jež tehdy byla hlavním centrem sociologických aktivit v Polsku díky tomu, že zde působili zejména Józef Chałasiński a Stanisław Ossowski. K nim a rovněž k dílu Floriana Znanieckého, jenž však těsně před vznikem druhé světové války natrvalo emigroval do USA, se Kłoskowská po celý svůj život hlásila jako ke svým učitelům a jako $\mathrm{k}$ vědcủm, kteři ji metodologicky, teoreticky, ale i svým tematickým zaměřením nejvíce ovlivnili a jimž nikdy nepřestala projevovat svou vděčnost a úctu.

Kłoskowská nezahajovala svou akademickou a badatelskou dráhu v době, jež by byla sociologické práci příznivá. Podobně jako u nás i v Polsku byla, jak známo, na přelomu 40. a 50. let sociologie jako studijní i vědecký obor zrušena. Nicméně právě v Lodži na rozdil od jiných polských sociologických pracovišt se podařilo pod vedením J. Chałasińského a J. Szczepańského přes velké institucionální i obsahové zvraty udržet pủvodní skupinu věnující se sociologii v podstatě beze změn, ovšem za cenu, že se přeorientovala na dějiny sociálního myšlení. $\mathrm{Z}$ tohoto období vytěžila Kłoskowská svou habilitační práci, nazvanou Machiavelli jako humanista na pozadí italské renesance, jež byla publikována roku 1954. Avšak i poté, kdy se od poloviny padesátých let sociologie v Polsku opět mohla rozvíjet, se Kłoskowská mnohokrát $\mathrm{k}$ problematice dějin sociálního myšlení vracela a věnovala této tematice řadu vynikajících studií. Tak např. v roce 1973 vyšla její stat Machiavelliho společenská teorie a roku 1975 rozsáhlá studie Nástin obrazu vývoje sociálního myšlení.

Posledně jmenovaná práce je cenným příspěvkem $\mathrm{k}$ chápáni předmětu dějin sociálního myšlení. Stanoví základní metodologické i teoretické principy jejich pěstování, nastiňuje jejich vztah ke vzniku a vývoji sociologie a upozorňuje rovněž na smysl jejich studia a výuky. Podle Kłoskowské zahrnujî dějiny sociálního myšlení dlouhé období vývoje názorů na společnost a společenské soužití lidí, jehož poslední fází je vydělení sociologie jako speciální discipliny. V jistém smyslu je tedy sociologie, která dosáhla postavení akademického předmětu studia a výuky, Kłoskowskou chápána jako aktuální etapa rozvinutého a dozrávajícího, ne-li zralého sociâlního myšlení.

Vymezením, které nejlépe odpovídá různorodosti podob a funkcí, jaké ve svých dlouhých dějinách sociální myšlení plnilo, se Kłoskowské zdá být pojem reflexe o společnosti a vzájemných vztazích lidí. Tato reflexe, v závislosti na stupni společenského vývoje a typu kultury, je obsažena v mýtech, implikována normami, morálními doporučeními a přislovími, shr- nujícími zkušenosti „lidové moudrosti“, a je vyjadřována filozofickými systémy, prolegomeny a odbočeními historických popisủ, teologickými sumami a právnickými traktáty. Dozrávajíc k sebepoznání, nabývá forem pojednání ze sociální filozofie a sociálni technologie, aby konečně, když odhalí vlastní specifiku a odlišnost, byla nazvána sociologií.

$\mathrm{V}$ základech tohoto procesu je podle Kłoskowské trvalý mechanismus; který se aktualizuje v každé generaci a v každém individuálním vkladu do obecného průběhu vývoje, sociálněpsychologický mechanismus vlastní „druhové povaze člověka“" zajisté už od okamžiku, kdy se vydělila během antropogeneze. Je to vědomi společenských procesů, druhová schopnost a nutnost reflexivního zaujetí stanoviska $\mathrm{k}$ vlastním souvislostem $\mathrm{s}$ jinými lidmi, jsou to jejich neustálé přeměny z faktủ existujících o sobě v existující také pro člověka, který je zakouší.

Odraz společenské skutečnosti v lidském vědomí, internalizovaný $\mathrm{v}$ rủznorodých, intersubjektivně dostupných symbolických formách, to je právě sociální reflexe, jejiž mnohotvárné projevy a dlouhý vývoj jsou předmětem dějin sociálního myšlení. Samotným sepětím s přirozenými vlastnostmi druhu je to $z$ hlediska svého rozsahu univerzální proces, jehož prủběh je však diferencovaný. Pouhý nástin syntézy jeho obecných dějin je podle Kłoskowské úkolem tak obtížným, že chopit se jej by při současném stavu poznání bylo intelektuální opovážlivostí.

V další části stati se Kłoskowská zabývá metodologicky neobyčejně závažnou otázkou, na jakých principech látku dějin sociálního myšlení zpracovávat a jak ji $z$ hlediska výuky zejména studentů sociologie vykládat. Je přesvědčena, že nelze zưstat u prostého chronologického výčtu jejich nejvýznamnějších představitelů (i když zvláště studenti musejî mít o jejich následnosti a hlavních názorech určité elementární poznatky), ale že je třeba látku zpracovávat $z$ hlediska její jisté vnitřní vývojové logiky. Je tomu tak zejména proto, že dějiny sociálního myšlení autorka chápe jako vývojový proud vedoucí od počátků lidového vědění $\mathrm{k}$ moderní specializované vědě o společnosti. Základem vědění o společenských jevech krystalizujících ve vědecké systémy je pro ni uznání zákonitosti těchto jevů, kterou lze formulovat $v$ podobě zákonů různého charakteru a stupně obecnosti. Protože vývoj sociologie se podle Kłoskowské realizoval v dlouhém procesu sociální reflexe, stále zřetelnĕji si uvědomující své deterministické stanovisko, zdá se jí správné, aby sledování právě tohoto procesu bylo vůdčím motivem konstrukce jejích dějin. 
Autorka je si vědoma, že přijmeme-li za základ této konstrukce zkoumání vývoje deterministických koncepcí, musíme nejprve determinismus definovat. Podle ní však může být přijato pouze nejširší chápání tohoto pojmu, které zahrnuje jak determinismus jednoznačný a krajní, tak i nejednoznačný a umírněný. Je také nutné, aby pojetí determinismu odpovídající různým obdobím sociální reflexe bylo dostatečně široké. Sama Kłoskowská se hlásí k definici, která vymezuje determinismus jako charakter pořádku jevů, podle něhož každý element závisí na určitých jiných elementech takovým zpủsobem, že mủže být předvídán, vyvolán nebo vyloučen potud, pokud jsou známy, vyvolány nebo vyloučeny podmiňujíci elementy. Autorka posléze dospívá $\mathrm{k}$ závěru, že takovéto široké chápání determinismu jako principu vzájemné závislosti sociálně-kulturních jevů je vlastnim základem moderního chápání společenských faktů jako systémů.

Vznikání sociologie bylo tudiž podle Kłoskowské dlouhým a obtižným procesem, který byl v jistém smyslu kontinuitní, procházel však etapami, jejichž rozlišení je nesporně zdủvodněné. Na druhé straně se ji ale nezdá správné vést mezi vývojovými fázemi, a to včetně té, která odděluje vývoj sociálního myšlení od vlastní sociologie, přiliš ostré hranice. $S$ touto výhradou interpretuje názor francouzského autora A. Akouna (charakterizující podmínky vzniku sociologických teorií), podle něhož se sociologie rodí a může zrodit pouze ve společnosti, která si klade otázky, jež se týkají jí samé, která zpochybnuje své normy a činí problémem svou existenci i své činnosti, ve společnosti, která se už nedomnívá, že je zakotvena ve vnějším řádu a nepovažuje už své instituce za přrirozené fakty.

Sociální reflexe se začíná rozvíjet, je-li alespoň část $\mathrm{z}$ uvedených podmínek splněna. Avšak Kłoskowské se zdá, že první elementární podmínka spočívající v kladení otázek vztahujících se $\mathrm{k}$ vlastní prìrozenosti se objevuje se společností samou jako důsledek „,druhové povahy člověka“. Vývoj sociálního myšlení začíná tudiž autoreflexí původní společnosti. Dějiny sociálního myšlení mají sledovat jeho dozráváni do stadia, kdy se objevuji sociologické teorie.

Výše uvedený princip výběru elementů těchto dějin vede $\mathrm{k}$ volbě autorů, jejichž teorie prezentované monograficky je možno zařadit do proudů pojatých způsobem směrujícím $k$ syntéze. Tyto teorie jsou chápány jako orientační body procesu, který sice nemůže být prezentován podrobně, ale nejplněji se v nich projevuje.

Za první orientační bod tohoto druhu považuje Kłoskowská informace týkající se myšlení prvobyt- něpospolné společnosti, které múžeme najít u kulturních a sociálních antropologů a etnografủ. $\mathrm{V}$ bohaté dokumentaci činnosti pủvodního člověka jako myslitele a filozofa jsou obsaženy četné př́klady sociální reflexe průkazně zjištujîcí, že také uvedená společnost si klade otázky týkající se jí samé. Odpověd na ně je podle autorky obsažena v mýtech.

Mnohem zralejší typ sociálních koncepcí reprezentuje řecké filozofické myšlení, na jehož vybraných představitelích (sofistech, Platónovi a Aristotelovi) autorka projevy deterministického pojetí společenských otázek demonstruje.

V synteticky pojatém vývoji novověkého sociálního myšlení, jež je pro Kłoskowskou dalším orientačním bodem, mủžeme podle ní rozlišit dvě protikladné koncepce determinismu. Jedna hledá zdroje sociální podmíněnosti ve faktorech prostředí, druhá $\mathrm{v}$ psychických vlastnostech jedince, $\mathrm{v}$ lidské přirozenosti. První vystupuje nejčastěji v podobě geografického a někdy také sociálněekonomického determinismu (Ibn Chaldun, Bodin, Turgot, Montesquieu, Rousseau), druhá, spjatá s redukcionistickým pojetím společnosti, je typická pro teoretiky prirozeného stavu a přirozeného práva (zejména pro Hobbese, Locka a fyziokraty).

Ve vývoji deterministických názorů na společnost, a tím i ve vývoji společenských věd učinil pak podle Kłoskowské další dủležitý krok Condorcet, a to svým rozlišením zákonů obecných (bezvýjimečných) a zákonů statistických.

Jiný zvláštní orientační bod $v$ pojetí logiky vývoje sociálního myšlení zkonstruované polskou autorkou tvoři teorie $z$ oblasti filozofie dejjin. V tomto př́ipadě mohou totiž dějiny sociálního myšlení sledovat koncepce sociálního determinismu, který se realizuje nikoli v samé strukturální závislosti synchronních jevů, ale ve vývoji lidstva pojatém jako jeden proces. Pro vymezení charakteru těchto zákonů se autorce zdá být nejsprávnější pojem zákonů genetických, které formulovali v 18. století zejména Vico, Turgot, encyklopedisté, Herder a Condorcet. V dalším století pak vytyčila problém obecných zákonů společenského vývoje spjatých s principem historismu teorie Marxova a Engelsova.

Kłoskowská si uvědomuje, že takto in nuce prezentovaná a vybranými př́klady ilustrovaná koncepce syntetizujícího pojetí dějin sociálního myšlení nutně mnoho elementů pomíjí a způsob prezentace materiálu modifikuje s cílem učinit principy selekce a analýzy zřejmými. V úplném nástinu dějin se musi kromě uvedených podstatných problémů přihlédnout $\mathrm{k}$ otázkám geneze společnosti a státu, $\mathrm{k}$ jejich definicím, identifikaci nebo rozlišení, ke 
koncepcím sociální struktury, zvláště tříd i jejich vzájemných vztahů, k pojetí vlastnictví a moci, jakož i forem systému a jejich přeměn. Jestliže $\mathrm{v}$ některých případech nejsou tyto problémy $\mathrm{v}$ přijatém interpretačním schématu zcela obsaženy, pak je třeba v určitých bodech jednotu principu syntézy spíše obětovat a opustit než jistý dủležitý element dějin sociální reflexe pominout. Autorce se však zdá, že mnoho takových podstatných otázek, jež by načrtnuté schéma překračovaly, neexistuje.

Kłoskowská je přesvědčena, že dějiny sociálního myšlení mají velké didaktické hodnoty. Její mnohaletá pedagogická zkušenost jí umožňuje tvrdit, že zájem studentů o ně je dobrým ukazatelem intelektuálních schopností a aspirací. Umožňuje s velkou pravděpodobností předvídat jejich další úspěchy ve studiu i v pozdější vědecké práci.

Sociální reflexi v jejích různorodých historických podobách považuje Kłoskowská za podstatnou složku symbolické kultury lidstva. Tato myšlenka vhodně spojuje zájmy polské autorky o dějiny sociálního myšlení s tematikou, jîž věnovala ve své vědecké i pedagogické práci největší pozornost, a tou je sociologie kultury. Na ni se zaměřila od prelomu 50. a 60. let na Lodžské univerzitě, kde pủsobila od roku 1976, i poté, když až do konce života byla profesorkou Varšavské univerzity. Výsledkem její badatelské činnosti jsou čtyři monografie, $\mathrm{z}$ nichž každá znamenala $\mathrm{v}$ dané tematické oblasti výrazný teoretický i metodologický posun jak $\mathrm{v}$ rámci polské, tak i světové sociologie. Jde o tyto práce: Masová kultura (1964), Společenské rámce kultury (1973), Sociologie kultury (1981) a Kořeny národnich kultur (1996). Za jakousi závěrečnou kvintesenci jejích kulturologických názorů lze považovat rozsáhlé, dvanáctistránkové heslo Kultura, které napsala pro 2. svazek polské Sociologické encyklopedie $\mathrm{z}$ roku 1999.

Pojem kultury patři podle autorky do základního repertoáru teoretického jazyka sociologie. Na konci 20 . století bývá sociologické chápání kultury redukováno na koncepce, které jsou vlastní studiu konkrétních oblastí, tj. jazyka, náboženství, vědy, literatury, umění a zvyků, což je na škodu obecné reflexi vztahující se na kulturu jako předmět sociologických teorií. Takovéto rozčlenění kultury zatlačuje do pozadí problémy, jež jsou pro obecnou sociologickou teorii zásadní, tj. kritéria rozlišení sféry jevů společenských a kulturních, jakož i vymezení jejich vzájemných souvislostí, které však neznamenají totožnost.

Když se Kłoskowská zabývá původem kultury a jejím vztahem $\mathrm{k}$ přirodě, konstatuje, že se kultura vyvozuje fylogeneticky $\mathrm{z}$ přírody. $\mathrm{V}$ teorii, která je osvobozena od metafyziky, jí nelze priznat jiný empiricky zachytitelný zdroj. Avšak ontogeneticky, ve vývoji lidských jedincủ prakticky dostupných empirickému zkoumání, nemůže být kultura z př́irody přímo vyvozena. Mezi individuálním lidským bytím a jeho genetickými základy leží historická akumulace výsledkủ kolektivní tvorby a recepce vytvořených hodnot, významů a předmětů, které předávány socializací a kulturalizací nejenže „ohýbají" lidskou větvičku určitým směrem, ale formují i její rủst.

Ve světle empirie by žádný člověk nebyl s to individuálně, v izolaci vytvořit ani tu nejchudši, nejprostši z těch kultur, s nimiž se setkáváme u nejpủvodnějších lidských skupin objevených badateli. Lidé patří $\mathrm{k}$ druhủm žijicím kolektivně. Kolektivní soužití je jednou z přirozených podmínek toho, že vytvářejí kulturu, tj. normy, významy a jejich nositele, jakož i čistě instrumentální předměty.

Sociologické pojetí kultury je podle Kłoskowské relativistické, nebot spočivá ve zjištění, že existuje souvislost hodnot a významů s lidskými postoji a znakotvornými činnostmi, jež ony hodnoty a významy podmiňují. Zvláštnost sociologie kultury je dána tím, že vyčleňuje $\mathrm{z}$ celé oblasti antropologického chápání kultury určitou kategorii a hledá jeji sepětí $\mathrm{s}$ tou sférou kultury, která je specificky společenská neboli societální, odvozená od společnosti. Tuto sféru tvoři sociální struktura jako sít rolí, statusů, jejich vztahů, kruhů a skupin jednajících lidí i jejich širších, nadřazených celkủ. Sociologie kultury je pěstována hlavně jako zkoumání výše uvedených oblastí $s$ přihlédnutím $\mathrm{k}$ široce pojatému studiu komunikace, tj. hromadných sdělovacích prostředkủ, jejich organizace, obsahu a přijemců.

Kłoskowská upozorňuje, že ve sfére pojmủ o kultuře existují stále zmatky a nejasnosti. Základní význam připisuje rozlišení toho, co je v kultuře znakem a pouze znakem, a toho, co výlučně jako znak nemůže $\mathrm{v}$ oblasti kultury skutečnosti plnit funkci. Nástroje, ošacení, jídlo či instituce vězení mohou být chápány také jako znaky, ale uspokojujî určité přirozené a společenské potřeby nikoli jako znaky, nýbrž ve fyzickém řádu světa. I v lidských vztazích tvořících čistě společenskou a verbálnî sféru kultury se kromě semiotických a symbolických interakcí objevuji činnosti a instituce, jež se neomezují na znaky.

Symbolická kultura se však realizuje ve sféře lidských pocitủ, estetických, citových a intelektuálních prožitkủ. Jako kategorie znakủ má smyslově zachytitelné významové nositele, ale označené před- 
měty jsou zde hodnotami a způsob jejich interpretace není jednoznačný. Tato kultura je sférou bezprostředního uspokojování specifické kategorie lidských potřeb, pro něž je zakoušení hodnot samo o sobě cílem. S odvoláním na Ossowského označuje autorka podstatu symbolické kultury jako autotelickou. Je to ta oblast kultury, která zasluhuje zvláštní pozornost, protože je specificky lidská. Zahrnuje zejména umění, vědu v jejím poznávacím aspektu, náboženství jako sféru kontaktů s posvátným, ale také hry a širokou oblast ludických činností.

Pojem autotelické symbolické kultury nevede k žádným omezením. Vztahuje se i na populární zábavnou kulturu, neredukuje se tudíž na kulturu vyšší. Jde o kulturu mnohotvárnou a multidimenzionální. S ohledem na svou symbolickou autoteličnost může být jako sféra čistých hodnot odlišena od societální kultury v oblasti reálné hry a reálného boje o sociální pozice, $\mathrm{v}$ oblasti formování rolí, vytváření a pretetváření společenských vztahủ i dosahování materiálních hodnot. Rozlišení kultury societální a kultury symbolické je podle Kłoskowské nutné proto, aby se mohla odlišit sociologie kultury jako subdisciplina, a to jak od kulturni antropologie, tak od speciálních výzkumů města, rodiny, výchovy, a také jako širší disciplína, než je sociologie literatury, vědy, náboženství i prostředkủ sdělování a př́jmu umění.

Oddělení symbolické kultury od společnosti má ovšem analytický charakter. Kultura se vždy realizuje $v$ šířeji nebo úžeji chápaných společenských rámcích. Ưkolem sociologie je podle Kłoskowské studium vazeb a vzájemných vlivů těchto dvou sfér. Autoteličnost symbolické kultury není na přkážku tomu, že je využivána $\mathrm{k}$ dosahování praktických společenských cílů - v politické propagandě, $\mathrm{v}$ obchodní reklamě nebo ve výchově. Právě podstata autotelických hodnot to naopak umožňuje. $V$ tom prípadě plní roli vnadidla. Jejich instrumentální účinnost však závisí na tom, zda jsou autentickými autotelickými hodnotami pro př́jemce a zda si přjjemce skutečnost, že jsou takto využívány $\mathrm{k}$ podstatně odlišným cílům, neuvědomuje.

$\mathrm{V}$ posledních letech svého života věnovala Kłoskowská intenzivní pozornost problematice národních kultur tváři v tvár̆ globalizačním procesủm a teoriím postmodernismu. Vycházela pr̆i tom $\mathrm{z}$ přesvědčení, že kultura $\mathrm{v}$ sociologickém pojetí je vždy subjektivizovaná, vztažená ke svým tvůrcům i uživatelům, kteři jsou zároveň objekty jejího formativního působení. Jedním ze základních definičních znakủ kultury $\mathrm{v}$ antropologii i v sociologii je shoda jejích hodnot $v$ rámci sociálních skupin, kate- gorií a kolektivit. Subjektivita kultury může mít rủzný rozsah v závislosti na velikosti kolektivit, $v$ nichž se realizuje, i v závislosti na bohatství společných hodnot. Zvlášt širokými kulturními pospolitostmi jsou národní kolektivity. Aby předešla kritice této teze, autorka upozorñuje, že shodou národních hodnot nechápe úplnou identitu kulturního vědění, norem a praktik v rámci celé zkoumané kolektivity. Uvědomuje si, že moderní národy jsou uvnitř nejen třídně, stratifikačně, regionálně i profesionálně diferencované, ale že jsou diferencované i z hlediska úrovně vzdělání, skupinových afiliací i individuálních kulturních voleb. Nadto nejsou izolované, ale $\mathrm{v}$ různém stupni a různou měrou proniknuté vnějšími vlivy. Jejich symbolická kultura není monolitní. Empirické výzkumy však potvrzuji existenci podstatných či vůdčích hodnot, jež jsou jednotlivým národům vlastní. Jedním $\mathrm{z}$ dủležitých konstitutivních faktorů většiny národů je národní jazyk. V některých kolektivitách mủže tuto roli plnit náboženství, soubor relativně trvalých národních mýtů a zejména pocit historické kontinuity. Akceptace těchto hodnot zajištuje národním kolektivitám pocit pospolitosti a tvoří základ národní identifikace jedinců.

Za oporu přijetí národní kultury individuálním vědomím bývá považováno osvojení alespoň části vůdčích hodnot $i$ jejího obsahu, vymezených jako kánon, neboli těch prvkủ, které jsou uznávány pro danou národní kulturu za zvlášt důležité a charakteristické a které tvoři vzor rozvoje kulturního bohatství i jeho zvlášt trvalý element.

Kłoskowská konstatuje, že na konci 20 . stoletî sílí tendence působící proti udržování kánonů a zvláštností národních kultur, čemuž napomáhá ideologie postmodernismu negující závaznost a trvalost kulturních vzorů. Tato ideologie je však podle ní elitární a nemá na kulturní praxi včetně praxe edukativní širší vliv. Dủležité je naopak působení kulturní difuze, která nabývá v dủsledku neustálého zdokonalování sdělovacích technik a v důsledku informační revoluce dřive nebývalých rozměrů. Podstatným faktorem, jehož význam však není plně doceněn, je především ekonomické a politické sjednocování velkých civilizačních oblastí, které má formu evropského společenství a šǐreji globalismu. Není to však tendence jediná. $V$ politické a národní sfére proti ní pủsobí odlišný proces národní diferenciace, separace a požadavků suverenity. Spolu s emancipačními politickými snahami malých či nových národủ a také vedle nich se objevují postuláty souběžného uznání dílčích symbolických kultur včetně kultur menšin. 
Za určitou formu reakce na postupující globalizaci považuje Kłoskowská regionální hnutí. Vzniká otázka, zda jsou také odpovědi na eventuální oslabení národní vazby, zda je lze považovat za její zástupnou formu. Další otázkou je, zda kulturní globalizace nesetře národní zvláštnosti a nezredukuje národní pospolitosti do role lokálních regionů, nebo je dokonce nenahradí spletí malých vlastí. $V$ předpokládané budoucnosti nám to podle Kłoskowské nehrozí. Védomě se zde hovoři o hrozbě $s$ ohledem na nebezpečí sterilizujicí jednolitosti a emocionálního vakua, jež by byly důsledkem oslabení nebo zániku ideologické funkce vlasti založené na dlouhodobé paměti a reálné nebo představované tradici. Nemenši hrozbou jsou tendence stavějící se proti zániku národního charakteru, vedoucí k nacionalistickému fundamentalismu. Autorka se domnívá, že východiskem $\mathrm{z}$ tohoto dilematu je pojetí národa jako „otevřené pospolitosti“.

Národní kulturu lze podle Kłoskowské vymezit jako syntagma. Tento lingvistický termín umožňuje zdůraznit vzájemnou adhezi, sepětí různých oblastí, jež ji tvoři. Tyto historické vazby nebyly ohroženy pozvolným, selektivním včleňováním vnějších obsahů, jež je pro národní kulturu nezbytné. Kompaktnost kultury zajištoval zejména princip kánonu jako jejího integrujícího základu.

Současná móda postmodernismu atakuje kánony shora. Naopak zdola přichází nápor populární kultury, jež není ani tak univerzální jako spíše uniformizovaná. Proti těmto tendencím působí ve světovém měřítku ohniska kultury odlišná od západní tradice, jejichž protikladnost nabývá někdy nebezpečných fundamentalistických forem. Kulturní globalizace a integrace má rủzné podoby a probíhá $\mathrm{v}$ různých rovinách.

Kłoskowská v této souvislosti vytyčuje několik otázek, o nichž se domnívá, že právě sociologie je povolána, aby se jimi v lokálním i světovém měřítku zabývala: Znamená globalizace také univerzalizaci současných kultur? Napomáhá vytváření pospolitostí, nebo spíše jejich staré formy založené na národních kritériích oslabuje? Podporuje toleranci a sbližování lidí, nebo tím, že oslabuje národní pospolitosti, zbavuje lidi v emocionálně vypjatých momentech i v nejběžnějších situacích každodenního života opory i pocitu něčeho cenného, tj. jednotných hodnot? Osvobozuje lidi od hrozby nacionalismu? Čím může pocit pospolitosti založený na vazbě $\mathrm{k}$ vlastním hodnotám nahradit?

Profesorka Kloskowská patřila řadu desetiletí mezi nejvýznamnějši polské sociology a vysokoškolské učitele. Práci s nástupci a pokračovateli z rad studentủ, doktorandů i mladých pedagogických pracovníků považovala za dủležitý a odpovědný úkol, čímž se výrazně podílela na zajištování úspěšného rozvoje polské sociologie i v budoucnosti. Jeji vědecké aktivity byly mj. oceněny tím, že roku 1973 byla jmenována členkou-korespondentkou a o deset let později řádnou členkou Polské akademie věd. Od roku 1983 až do své smrti byla hlavní redaktorkou čtvrtletníku Kultura i Spoteczeństwo, který dlouhodobě patří $\mathrm{k}$ nejdủležitějším a nejkvalitnějším polským časopisủm zabývajícím se humanitní problematikou. $V$ nezvykle dynamické a dramatické době velkých společenských přeměn velice úspěšně a způsobem pro celou polskou sociologii neobyčejně plodným a prospěšným plnila $v$ letech 1989-1994 velmi náročnou a zároveň v Polsku nesmírně ceněnou a prestižní funkci předsedkyně Polské sociologické společnosti.

V kontextu české sociologie se př́ této přiležitosti sluši připomenout dvě skutečnosti. Prof. Kłoskowská spolu s dalšími sedmnácti polskými sociology byla členkou vysoce reprezentativni delegace, která se pod vedením Jana Szczepańského zúčastnila ve dnech 10.-13. dubna 1967 prvního setkání čs. a polských sociologů ve Smolenicích. Tehdy mělo zmíněné setkání pro obě strany velký význam, nebot přispělo $\mathrm{k}$ vzájemnému poznání vědeckých výsledkủ i budoucích výzkumných záměrủ. Spolupráce čs. a polských sociologů se již několik let na nejrůznějších úrovních bohatě rozvíjela a smolenické jednání pro ni znamenalo další cenný impulz. Změněná politická situace po srpnu 1968 a zejména „,normalizačníc zásahy do institucionální a personální struktury čs. sociologie však plnění společně domluvených konkrétních výzkumných plánů znemožnily.

Trvalou stopu v naší sociologii zanechala A. Kłoskowská díky tomu, že poměrně brzy po polském vydání vyšel v květnu 1967 nákladem tř̌ tisíc výtiskủ v Sociologické knižnici nakladatelství Svoboda český překlad její knihy Masová kultura. $\mathrm{V}$ dané tematické oblasti šlo u nás tehdy o knihu ojedinělou, která mapovala sféru našimi sociology, ale i badateli $z$ jiných, príbuzných oborů téměř nedotčenou. Přitom cenné pro české čtenáře nebylo jenom samo jádro práce, v němž se autorka zabývala prostředky masové komunikace, vymezením masové kultury, historickými podmínkami jejího vzniku, takovými pro ni charakteristickými pojmy, jako je princip společného jmenovatele a princip homogenizace, vývojem její kritiky, jejím vztahem $k$ tzv. vyšší kultuře a jejími dalšími perspektivami, ale také ty 
části knihy, jež byly autorčinými příspěvky k obecným otázkám vytváření pojmu kultury, k pojetí kultury v kulturní antropologii a v sociologii, ke vztahu kultury a společnosti, ke dvěma typům sociální vazby a $\mathrm{k}$ sociologickým otázkám volného času. Zmíněná kniha byla pro nás zároveň neocenitelnou informací o tom, jaký je aktuální stav této problematiky v západní sociologické a kulturologické literatuře, nebot Kłoskowská tuto literaturu perfektně znala, na mnoha místech $\mathrm{z}$ ní vycházela a citovala ji. Zdá se mi, že ani dnes, téměř čtyřicet let poté, co byla kniha napsána, neztratila nic na své hodnotě. Troufám si dokonce tvrdit, že mnohé její závěry týkající se kritiky masové kultury a hledání cest, jak se v rozvoji masové kultury, který autorka realisticky považuje za nezadržitelný, vyvarovat jejího úplného odtržení od obsahủ tzv. vyšši kultury i její banalizace, jsou dnes u nás mnohẹm aktuálnější než $v$ době, kdy kniha v českém překladu vyšla. Tehdy šlo totiž až na výjimky o problematiku, jež pro nás byla spíše teoretická a zkušenostem $s$ čs. kulturním životem šedesátých let vzdálená. Mocenský převrat z listopadu 1989 a jím zahájená restaurace kapitalismu však způsobily, že stupidita, primitivismus, hloupost, prostomyslnost, tupost, schematičnost a neuvěřitelně nízká intelektuální úroveň převážné části výplodů zejména americké masové kultury, které se $\mathrm{k}$ nám dostávají a jimž se velmi iniciativně přizpůsobili mnozi domácí „tvůrci“ i sdělovací prostředky, slaví dnes u nás pravé orgie a staly se vážným praktickým sociálním problémem. A právě mj. náznaky jeho řešení, poučenými tím, jak úpadkové formy masové kultury kritizovali někteři západní intelektuálové 50. a 60. let, je kniha Kłoskowské dodnes aktuální a podnětná.

Protože jsem měl možnost se při své návštěvě ve Varšavě v polovině 60 . let s prof. Kłoskowskou setkat, mohu v závěru této vzpomínky na ni potvrdit slova předsedy Polské sociologické společnosti A. Kojdera, který ve smutečním projevu nad její rakví prohlásil, že kontakt s ní byl zdrojem uspokojení, a to nejen intelektuálního, ale také morálního a emocionálního, že tímto zvláštním zpủsobem obohacovala život všech svých žáků a spolupracovníků a že všem ostatním zanechala poklad neméně cenný: svůj myšlenkový odkaz.

O generaci mladší Edmund Mokrzycki studoval sociologii a filozofii $v$ druhé polovině 50 . let, $\mathrm{v}$ době plné nadějí spjatých $\mathrm{v}$ Polsku s velkými politickými změnami vyvolanými říjnem 1956, kdy se zdálo, bohužel - jak se později ukázalo - mylně, že polská společnost definitivně skoncuje se všemi projevy stalinismu. Pro sociology bylo významné, že pod vlivem této změněné atmosféry se sociologie v Polsku znovu institucionalizovala, jako studijní obor se vrátila na vysoké školy, navázala na své bohaté tradice, vstoupila do živých a mnohostranných kontaktů se západními, zejména americkými sociology a sociologickými pracovišti a zahájila široce koncipované empirické výzkumy. Je podstatné, že od této doby, přes všechny rủzné peripetie způsobené politickými zvraty, na něž bylo Polsko v druhé polovině 20. století zvlášt bohaté, polská sociologie již nikdy neztratila charakter „normální vědy“, rozvíjela se standardním způsobem a získala i v mezinárodním měřitku všeobecně uznávané postavení. Celé Mokrzyckého dílo bylo výrazně pozitivně ovlivněno právě obdobím, ve kterém studoval, kdy jeho učiteli byly mj. vynikající a charismatické osobnosti Stanisława a Marie Ossowských. Mnohé pro svou vědeckou činnost i pro své postoje získal rovněž od starších spolupracovníků, legend polské sociologie i sociálněpolitické publicistiky, Stefana Nowaka a Jana Strzeleckého. Svým dílem ani občanskými postoji nezůstal Mokrzycki těmto svým učitelům a vzorům nic dlužen, šel v jejich stopách a jako představitel další generace výrazně přispěl k úspěšnému rozvoji polské sociologie druhé poloviny 20. století.

Svoji akademickou dráhu zahájil jako učitel Varšavské univerzity, od roku 1973 pracoval v Institutu filozofie a sociologie Polské akademie věd, počátkem 90. let zde spoluzakládal Školu společenských věd a od roku 1995 byl ředitelem oddělení sociologie Středoevropské univerzity ve Varšavě, kde se podílel na výuce a výchově studentủ a doktorandů $z$ různých evropských zemí. Učil rovněž na univerzitách v Chicagu, New Yorku, Berkeley, Bruggách, na několika vysokých školách v Holandsku a ve skandinávských zemích.

Řadu let byl členem redakčních rad významných polských (Studia Socjologiczne, The Polish Sociological Bulletin) i zahraničních (Sisyphos, The British Journal of Sociology) časopisủ. Dủležitou roli plnil v Polské sociologické společnosti, v Polské společnosti politických studií i v různých vědeckých radách a výborech.

Ve své vědecké práci se zaměřoval hlavně na problematiku sociologické teorie a metateorie, tzv. humanistické sociologie, vědecké a společenské racionality, teoretických a metodologických modelů v polské i světové sociologii a poznávacích i sociálních funkcí sociologie, jak o tom svědčí desítky jeho statí v odborných domácích i zahranič- 
ních časopisech, ale zejména dvě monografie: Předpoklady humanistické sociologie (1971) a Sociologie ve filozofickém kontextu (1990). Po roce 1989 věnoval intenzivní pozornost transformačním procesům, jejïmž výsledkem byly dvě práce, na nichž se autorsky a redakčně podílel spolu s Ch. Bryantem: The New Great Transformation a Democracy, Civil Society and Pluralism. Cenné jsou rovněž jím redigované nebo spoluredigované antologie, mj. Krize a schizma: antiscientistická tendence $v$ součas né sociologii (1984) a Fenomenologie a sociologie (1989).

Mezi polskými sociology patřil k nejpilnějším a nejvíce čteným publicistům. Ve svých článcích a statích psaných pro různé polské deníky a kulturněpolitické časopisy se zabýval zejména otázkami vědy, vztahy mezi tržním hospodářstvím a sociální strukturou, blokádami občanské společnosti, úkoly inteligence, formováním střední třídy, institucemi, hodnotami a zájmy polské společnosti i zvláštnostmi její transformace.

Z Mokrzyckého teoretické tvorby bych chtěl při této přiležitosti spíše symbolicky upozornit na některá místa $\mathrm{z}$ jeho první knihy, $\mathrm{z}$ jeho publicistiky pak na některé myšlenky ze stati, která byla uveřejněna týden po jeho smrti.

Jakkoli první Mokrzyckého knižní publikace nazvaná Předpoklady humanistické sociologie není nijak rozsáhlá (má celkem 115 stran menšího formátu), byla ve své době významná především ze tři důvodů: autor v ní rozlišil a vysvětlil dvojí možné chápání pojmu humanistické sociologie, což tehdy nebylo obvyklé, všestranně analyzoval klíčovou proceduru této sociologie, jíž je porozumění, a konečně šlo o explicitní polemiku s některými předpoklady empiristické sociologie, považované v určitém období za jedinou možnou cestu tzv. zvědečtěni sociologie, ale i (jak se domnívám) o implicitní polemiku s některými scientistickými a pozitivistickými tendencemi marxistických autorủ, podceňujícími roli subjektivních faktorů při konstruování sociální reality a v dějinách vůbec.

$\mathrm{Z}$ celé této problematiky se zaměřím na stručnou reprodukci pouze prvního tématu. Mokrzycki rozlišuje dvě koncepce humanistické sociologie. Jedna $z$ nich je sociologická a druhou nazývá metodologickou. První odvozuje z Millsovy kritiky empiristické sociologie, obsažené zejména $v$ díle Sociologická imaginace. Sociologie se podle Millse dá pěstovat dvojím způsobem: bud' rozvíjí sociologickou představivost, nebo formuluje předpoklady umožňující manipulovat $s$ lidmi. Někteři polští pokračovatelé millsovské vize zavedli podle Mok- rzyckého pro první z nich název sociologie humanistická, pro druhou název technická, manipulátorská nebo prostě nehumanistická.

Humanistická sociologie v tomto významu je tedy vymezena $z$ hlediska své sociální funkce. Je to sociologické vědění, které formuje lidské postoje a názory, je zdrojem společenských orientací, usnadňuje pochopení nejzávažnějších sociálních problémủ, inspiruje myšlení a rozvijí imaginaci. Její protiklad, tj. technická sociologie, je základem sociálního inženýrství, nástrojem obratného společenského jednání a zdrojem návodủ, jak lidi ř́dit nebo jak s nimi manipulovat.

Mokrzycki píše, že toto rozlišení se zdá být na první pohled zcela pochopitelné, avšak při bližším zkoumání se ukáže, že vyvolává určité interpretační těžkosti. Vypadá to tak, jako kdyby neexistovalo sociologické vědění, které lze zařadit zároveň jak do sociologie humanistické, tak i technické. Podle Mokrzyckého je jasné, že tyto dvě funkce se vzájemně nevylučují, mohou být plněny nejen týmiž díly, ale rovněž týmiž informacemi.

Zminěné chápání humanistické sociologie se konstituovalo během kritiky empiristické sociologie a sloužilo jako její nástroj. Právě empiristická sociologie byla ztotožňována se sociologickým věděním užitečným jedině $z$ technického hlediska. Mokrzycki se však domnívá, že tento názor neobstojí, jestliže se hlouběji seznámíme s takovými pracemi, jako je např. Stoufferovo dílo The American Soldier nebo jako jsou Lazarsfeldovy studie The People's Choice či The Academic Mind.

Ale príkladů, které zpochybňují uvedenou dichotomii, je podle Mokrzyckého více a není je třeba hledat pouze $v$ rámci empiristické sociologie. Autor $\mathrm{v}$ této souvislosti klade takovéto otázky: Kam zařadit velké množství prací sociálních reformátorủ, které jsou založeny na empirických výzkumech? Není oprávněné některé práce Malinowského, reprezentantů chicagské školy nebo samého Millse hodnotit vysoko jak z hlediska humanistické, tak i technické funkce? Jak po této stránce ocenovat díla, která jsou založena na monografických výzkumech, jako je Middletown manželů Lyndových?

Mokrzycki se ptá, zda na rozdíl od toho, jak se záležitost jeví na pruní pohled, to není náhodou tak, že veškeré podstatné sociologické poznatky mohou více nebo méně, prímo nebo nepřimo ovlivňovat jak sociologickou imaginaci, tak i sociotechnické pokyny. Pokud by tomu tak skutečně bylo, pak lze chápat humanistickou a technickou sociologii atributivně jako dva aspekty sociologického vědění, jako dva 
ideální typy, $z$ nichž jedním je nap̌r. vědění plnící pouze funkci humanistickou a druhým vědění, jehož společenská užitečnost se redụkuje na pokyny z oblasti sociálního inženýrství. Zdá se, že tento Mokrzyckého názor byl na začátku 70. let názorem př́nosným, a to nejen $v$ rámci polské sociologie.

Ve druhém Mokrzyckým rozlišeném významu se humanistická sociologie vztahuje na určitou kategorii metasociologických názorů, zejména těch, které se týkají předmětu a metod sociologických výzkumủ. V tomto smyslu jde podle polského autora o název klamný, nebot' humanistická sociologie $v$ takovémto pojetí není sociologií. Pouze ve výjimečných případech se tento název použivá rovněž pro označení sociologických prací, které se zmíněnými metasociologickými názory korespondují.

Myšlenky, o něž tu jde, zavedl do teorie vědy v nejzralejší a nejpropracovanější podobě W. Dilthey. Jsou obsaženy $v$ jeho úvahách o specifičnosti předmětu a metody humanitních věd. Sám Dilthey však tyto úvahy na sociologii nevztahoval, protože ji z humanitních věd vylučoval, chápaje ji jako disciplínu metafyzickou. Vyplývalo to ze skutečnosti, že termín „sociologie“ spojoval se spekulativními systémy Comta a Spencera. Kdyby tomu tak nebylo, byl by dnes Dilthey oprávněně považován nikoli za inspirátora a předchůdce humanistické sociologie, ale za jejího tvůrce a nejvýznamnějšího představitele. Nebyly to tedy podstatné obsahy hlásaných názorů, ale druhořadé okolnosti, které způsobily, že místo patř́ící Diltheyovi zaujal ve společenském vědomí $\mathrm{M}$. Weber.

Ideje tvoříí humanistickou sociologii se podle Mokrzyckého dají v každém případě vyvodit z Diltheyových úvah. Logická souvislost je zde jednoznačná. Jinak je to však se souvislostmi historickými. Dilthey zahájil pouze jednu linii $\mathrm{v}$ rámci humanistické sociologie. Druhá se vytvářela, a to, jak se zdá, úplně nezávisle na Diltheyovi, v rámci chicagské školy. Počátek první je zřetelný, počátek druhé mlhavý a velmi těžko stanovitelný. Přímým pokračovatelem Diltheye byl M. Weber. Formování chicagské školy by bylo správné spojit s takovými jmény, jako je Ch. H. Cooley, J. Dewey, G. H. Mead a W. I. Thomas. Je možné, že F. Znaniecki, R. McIver a P. Sorokin byli již dědici obou tradic, ale chicagská škola je ovlivnila mnohem více.

Tato dvojí geneze humanistické sociologie rozhodla o dost velkých jazykových rozdílech v jejím rámci. Mokrzycki píše, že tu jde nejen o rozdíly terminologické, ale i o jisté diference $\mathrm{v}$ pojmové aparatuře. Nestejně jsou exponovány jednotlivé složky této orientace. $V$ tradici chicagské školy je značně silnější akcent kladen na otázky předmětu sociologie než na otázky metodologické. A tak zde jde podle Mokrzyckého o určitou orientaci, nikoli o vědeckou školu. Spíše se dá říci, že v rámci této orientace existujî dvě školy. Jedna se vyvozuje z filozofických úvah, druhá $z$ analýzy vlastní výzkumné práce.

Již z této stručné reprodukce Mokrzyckého studie je zrejmé, že na počátku 70. let vnesla do úvah o humanistické sociologii některé nové a originální postřehy. Tento přistup byl pak typický pro celou autorovu dalši vědeckou tvorbu.

Dobrým př́kladem charakteristických rysů Mokrzyckého publicistiky je ona již výše zmíněná stat nazvaná Oswojony kapitalizm (dá se překládat jako Osvojený, ale také Ochočený kapitalismus), která vyšla v deníku Gazeta Wyborcza z 11.-12. 8. 2001. Mokrzycki v ní analyzuje základní systémové změny, k nimž došlo v Polsku od roku 1989, a kriticky se vyjadřuje $\mathrm{k}$ některým problémům současné polské společnosti. Vychází z teze, že uvedené změny jsou mnohem povrchnější, než by to vyplývalo $\mathrm{z}$ toho, jak Poláci hodnotí sami sebe a jak se o nich vyjadřují západní sdělovací prostředky.

Stat se zabývá vztahem revolučních a reformních prvků v transformaci polské společnosti, porovnává průběh pokusu o radikální tržní modernizaci cestou reforem zhora ve čtyřech zemích tzv. asijských tygrủ a v Polsku, upozorn̆uje, jak zprvu šoková terapie ekonomické reformy se postupně mění v systémový synkretismus, vznikající ani ne tak v důsledku kompromisu různých ideologických opcí, nýbrž jako výsledek živelných tlaků na stále bezideovější a zkorumpovanější politickou třídu, analyzuje rovněž hlavní procesy, k nimž dochází na politické scéně, problematiku tzv. nové chudoby, zásadní změny $\mathrm{v}$ postavení inteligence, přičemž zdůrazňuje degradaci její společenské role ve srovnání s minulými etapami vývoje polské společnosti a zmiňuje se rovněž o „usychání “ kultury, které s tím souvisí. Dủležité je, že autor nezůstává u pouhého popisu a konstatování těchto skutečností, ale snaží se rovněž vysvětlit jejich prričiny.

Ceský čtenář je doslova ohromen tím, kolik prvkủ této diagnózy se plně vztahuje také na naši společnost. Jako přiklad uvedme část Mokrzyckého úvah o současné polské politice, kde se říká, že poslední desetiletí znamenalo zploštění polské politiky tím, že byla redukována na technologii dosahování moci a maximálního využivání této kořisti k rozmnožování politického kapitálu, který ve zpolitizované ekonomice zlepšuje individuální i skupi- 
novou sociální pozici a přináší rovněž značné materiální výhody. Př́istup k moci se stal v Polsku ještě lepším nástrojem obohacování než v minulém režimu. Politická tř́ida demokratického Polska zachovala nebo přejala mnoho vlastností předdemokratické moci. Polský přiklad ukazuje, že ve východní Evropě procedurální demokracie sama o sobě nenutí $\mathrm{k}$ radikální změně stylu vládnutí. Ti, kteří $\mathrm{v}$ polské společnosti zjištuji konsolidaci demokracie, maji pravdu, ale pouze v čistě popisné sfére. Mýlí se však, ztotožňují-li tuto demokracii s realizací odvěkého snu o demokratickém Polsku. Klíč k němu totiž spočivá $\mathrm{v}$ rukou společnosti. Ta je ale bohužel silou pouze reaktivní. Přes obrovskou nespokojenost se všemi existujícími politickými složkami nedokáže vytvořit žádnou alternativu současných konstelací. A pokud se něco takového objeví, je to výsledek sporů mezi liberálními politiky, nikoli občanského politického hnutí rodícího se zdola.

Ještě v červnu 2001, krátce před svou smrtí, stačil Mokrzycki odevzdat do tisku dvě knihy, jedné $\mathrm{z}$ nich je spoluautorem a druhou napsal sám. Celná polská socioložka J. Kurczewská o nich v nekrologu Mokrzyckého napsala, že jejich nesporným hrdinou je nejnovějši podoba polské demokracie se všemi svými vnitřními těžkostmi a omezeními jak ve sféře hodnot, tak i institucí. Vlastní knížce dal Mokrzycki př́iznačný název Nesentimentální bilance. Zdá se, že je v něm dobře vyjádřeno krédo, jímž se řídil v celém svém životě, vědecké práci, publicistické tvorbě i pedagogické činnosti.

Jan Sedláček 